\title{
Arylene Ethynylene Macrocycles Prepared by Precipitation-Driven Alkyne Metathesis
}

\author{
Wei Zhang and Jeffrey S. Moore*
}

Roger Adams Laboratory, Departments of Chemistry and Materials Science \& Engineering, University of Illinois at Urbana-Champaign, Urbana, Illinois 61801

\section{Supporting Information}

General Procedures. Unless otherwise indicated, all starting materials were obtained from commercial suppliers and were used without further purification. All air or moisture-sensitive manipulations were performed under an atmosphere of argon using standard Schlenk techniques or in an argon filled glove box (model TS-5000 from Vacuum/Atmospheres Company). $\mathrm{CCl}_{4}$ was distilled over $\mathrm{P}_{2} \mathrm{O}_{5}$ and degassed before use. Analytical thin-layer chromatography (TLC) was performed on Kieselgel F-254 precoated silica gel plates. Visualization was performed with UV light (254 nm) or iodine stain. Flash column chromatography on all monomers and monomer precursors was conducted with silica gel 60 (230-400 mesh, $60 \AA$ ) from EM science. Flash column chromatography for macrocycles was conducted with silica gel 62 (60-200 mesh, $150 \AA)$ from Aldrich. Silica gel 62 was superior to silica gel 60 for macrocycle purification.

The ${ }^{1} \mathrm{H}$ and ${ }^{13} \mathrm{C}$ NMR spectra were recorded on 400 or $500 \mathrm{MHz}$ spectrometers in School of Chemical Science (SCS) VOICE NMR Laboratory at the University of Illinois (http://www.scs.uiuc.edu/ mainzv/VOICE_NMR_Lab/). Proton chemical shifts are expressed in parts per million $(\delta)$ using the residual solvent protons as an internal standard. Carbon-13 chemical shifts are also expressed in parts per million $(\delta)$ using the solvent's ${ }^{13} \mathrm{C}$ resonance as an internal standard. Coupling constants $(J)$ are reported in Hertz $(\mathrm{Hz})$, and splitting patterns are designated as s (singlet), d (doublet), $\mathrm{t}$ (triplet), $\mathrm{q}$ 
(quartet), m (multiplet) and br (broad). Low and high resolution EI, FAB and MALDI mass spectra were obtained in the SCS Mass Spectrometry Facility at the University of Illinois. Elemental analyses were performed by the University of Illinois Micro Analytical Service Laboratory. Gel permeation chromatography (GPC) measurements were performed in THF at $25{ }^{\circ} \mathrm{C}$ with a Waters 515 HPLC pump, Viscotek TDA model 300 triple detector, and a series of three Viscogel $7.8 \cdot 300 \mathrm{~mm}$ columns (two GMHXL16141 columns and one G3000HXL16136 column). Molecular weight data were determined using Viscotek's TriSEC software. The light scattering, mass, and viscosity constants were determined from a single $96 \mathrm{kDa}$ narrow polystyrene standard and checked for accuracy against other known polystyrene standards. The column exclusion limit was $1.0 \cdot 10^{7} \mathrm{Da}$, and the flow rate was $1.0 \mathrm{~mL} / \mathrm{min}$.

3,5-Dipropynyl t-butylbenzene (1a): Application of Negishi's general procedure for alkyne coupling ${ }^{1}\left[\mathrm{ZnBr}_{2}(2.84 \mathrm{~g}, 12.6 \mathrm{mmol}), 1\right.$-propynyllithium (0.621 g, $\left.13.5 \mathrm{mmol}\right)$, 3,5-dibromo-t-butylbenzene ${ }^{2}(1.31 \mathrm{~g}, 4.50 \mathrm{mmol}), \mathrm{Pd}\left(\mathrm{PPh}_{3}\right)_{4}(1.04 \mathrm{~g}, 0.90 \mathrm{mmol})$ in THF $(16 \mathrm{~mL})]$ gave the product as a light yellow oil $(0.92 \mathrm{~g}, 97 \%) .{ }^{1} \mathrm{H}$ NMR $\left(\mathrm{CDCl}_{3}, 500\right.$ MHz): $\delta 7.33(\mathrm{~d}, J=1.5 \mathrm{~Hz}, 2 \mathrm{H}, \operatorname{Ar} H), 7.23(\mathrm{t}, J=1.5 \mathrm{~Hz}, 1 \mathrm{H}, \operatorname{Ar} H), 2.04(\mathrm{~s}, 6 \mathrm{H}, \mathrm{C} \equiv$ $\left.\mathrm{CCH}_{3}\right), 1.28\left[\mathrm{~s}, 9 \mathrm{H}, \mathrm{C}\left(\mathrm{CH}_{3}\right)_{3}\right] ;{ }^{13} \mathrm{C} \mathrm{NMR}\left(\mathrm{CDCl}_{3}, 125 \mathrm{MHz}\right): \delta 151.5,131.8,128.3$, 123.9, 85.8 (Ar-C $\equiv C), 79.8(\mathrm{Ar}-\mathrm{C} \equiv \mathrm{C}), 34.8\left[C\left(\mathrm{CH}_{3}\right)_{3}\right], 31.3\left[\mathrm{C}\left(\mathrm{CH}_{3}\right)_{3}\right], 4.5\left(\mathrm{C} \equiv \mathrm{CCH}_{3}\right)$; LR-MS (EI): m/z (\%): 210 (100), 195 (90), 179 (62), 165 (70), 152 (53), 139 (11), 128 (18), 115 (12), 57 (24); HR-MS $\left(\mathrm{C}_{16} \mathrm{H}_{18}\right)$ : calcd 210.1409, found 210.1410; TLC $\mathrm{R}_{f}=$ 0.34 (n-Hexane). 
3,5-Dipropynylphenyl ether (1b): Application of Negishi's general procedure for alkyne coupling ${ }^{1}\left[\mathrm{ZnBr}_{2}(1.70 \mathrm{~g}, 7.54 \mathrm{mmol})\right.$, 1-propynyllithium $(0.347 \mathrm{~g}, 7.54 \mathrm{mmol}), 3,5-$ dibromophenyl ether ${ }^{3}$ (1.20 g, $\left.3.02 \mathrm{mmol}\right), \operatorname{Pd}\left(\mathrm{PPh}_{3}\right)_{4}(0.383 \mathrm{~g}, 0.33 \mathrm{mmol})$ in THF (10 $\mathrm{mL})$ ] gave the product as a light yellow oil $(0.66 \mathrm{~g}, 70 \%) .{ }^{1} \mathrm{H} \mathrm{NMR}\left(\mathrm{CDCl}_{3}, 400 \mathrm{MHz}\right)$ : $\delta 7.00(\mathrm{t}, J=1.5 \mathrm{~Hz}, 1 \mathrm{H}, \operatorname{Ar} H), 6.84(\mathrm{~d}, J=1.5 \mathrm{~Hz}, 2 \mathrm{H}, \operatorname{Ar} H), 4.07(\mathrm{~m}, 2 \mathrm{H}), 3.82(\mathrm{~m}$, $2 \mathrm{H}), 3.62-3.74(\mathrm{~m}, 6 \mathrm{H}), 3.54(\mathrm{~m}, 2 \mathrm{H}), 3.37\left(\mathrm{~s}, 3 \mathrm{H}, \mathrm{OCH}_{3}\right) 2.02\left(\mathrm{~s}, 6 \mathrm{H}, \mathrm{C} \equiv \mathrm{CCH}_{3}\right) ;{ }^{13} \mathrm{C}$ NMR $\left(\mathrm{CDCl}_{3}, 100 \mathrm{MHz}\right): \delta 158.2,127.4,125.0,117.2,86.0(\mathrm{Ar}-\mathrm{C} \equiv C), 79.0(\mathrm{Ar}-\mathrm{C} \equiv \mathrm{C})$, 71.9, 70.8, 70.6, 70.5, 69.6, 67.5, 59.0, $4.3\left(\mathrm{C} \equiv \mathrm{CCH}_{3}\right) ; \quad$ LR-MS (EI): $\mathrm{m} / \mathrm{z}(\%): 316.2$ (30), 214.1 (9), 196.1 (24), 170.1 (78), 141.1 (24), 103.1 (13); HR-MS $\left(\mathrm{C}_{19} \mathrm{H}_{24} \mathrm{O}_{4}\right)$ : calcd 316.1675, found 316.1672; TLC R $\mathrm{R}_{f}=0.35$ ( $n$-Hexane/EtOAc, 3/2, v/v).

3,5-Dipropynylbenzyl ether (1c): Application of Negishi's general procedure for alkyne coupling ${ }^{1} \mathrm{ZnBr}_{2}(1.38 \mathrm{~g}, 6.12 \mathrm{mmol})$, 1-propynyllithium $(0.270 \mathrm{~g}, 5.87 \mathrm{mmol}), 3,5-$ dibromobenzyl ether ${ }^{4}(1.05 \mathrm{~g}, 2.55 \mathrm{mmol}), \mathrm{Pd}\left(\mathrm{PPh}_{3}\right)_{4}(0.324 \mathrm{~g}, 0.28 \mathrm{mmol})$ in THF (10 $\mathrm{mL})$ ] gave the product as a light yellow oil $(0.74 \mathrm{~g}, 87 \%) .{ }^{1} \mathrm{H}$ NMR $\left(\mathrm{CDCl}_{3}, 400 \mathrm{MHz}\right)$ : $\delta 7.30(\mathrm{t}, J=1.5 \mathrm{~Hz}, 1 \mathrm{H}, \mathrm{ArH}), 7.25(\mathrm{~d}, J=1.5 \mathrm{~Hz}, 2 \mathrm{H}, \mathrm{ArH}), 4.47$ (s, $\left.2 \mathrm{H}, \mathrm{ArCH}_{2}\right), 3.52-$ $3.68(\mathrm{~m}, 12 \mathrm{H}), 3.37\left(\mathrm{~s}, 3 \mathrm{H}, \mathrm{OCH}_{3}\right) 2.02\left(\mathrm{~s}, 6 \mathrm{H}, \mathrm{C} \equiv \mathrm{CCH}_{3}\right) ;{ }^{13} \mathrm{C} \mathrm{NMR}\left(\mathrm{CDCl}_{3}, 100 \mathrm{MHz}\right)$ : $\delta 138.5,133.5,129.8,124.2,86.2($ Ar- $\mathrm{C} \equiv C), 79.0($ Ar- $C \equiv \mathrm{C}), 72.4,71.9,70.7,70.6$, 70.5, 70.4, 69.5, 59.0, $4.3\left(\mathrm{C} \equiv \mathrm{CCH}_{3}\right) ; \quad$ LR-MS (EI): $\mathrm{m} / \mathrm{z}(\%): 330.2$ (55), 182.1 (17), 167.1 (100), 152.1 (17), 82.9 (20), 59.0 (81); HR-MS $\left(\mathrm{C}_{20} \mathrm{H}_{26} \mathrm{O}_{4}\right)$ : calcd 330.1844, found 330.1838; TLC R $\mathrm{R}_{f}=0.15$ ( $n$-Hexane/EtOAc, 7/3, v/v).

3,5-Dipropynylbenzoate ester (1d): Application of Negishi's general procedure for alkyne coupling ${ }^{1}\left[\mathrm{ZnBr}_{2}(1.31 \mathrm{~g}, 5.80 \mathrm{mmol}), 1\right.$-propynyllithium $(0.257 \mathrm{~g}, 5.58 \mathrm{mmol})$, 3,5-dibromobenzoate ester ${ }^{5}(0.950 \mathrm{~g}, 2.23 \mathrm{mmol}), \mathrm{Pd}\left(\mathrm{PPh}_{3}\right)_{4}(0.309 \mathrm{~g}, 0.27 \mathrm{mmol})$ in 
THF $(10 \mathrm{~mL})]$ gave the product as a light yellow oil $(0.64 \mathrm{~g}, 83 \%) .{ }^{1} \mathrm{H} \mathrm{NMR}\left(\mathrm{CDCl}_{3}\right.$, $400 \mathrm{MHz}): \delta 7.94$ (d, $J=1.5 \mathrm{~Hz}, 2 \mathrm{H}, \mathrm{ArH}), 7.55(\mathrm{t}, J=1.5 \mathrm{~Hz}, 1 \mathrm{H}, \mathrm{ArH}), 4.45(\mathrm{~m}, 2 \mathrm{H})$, $3.81(\mathrm{~m}, 2 \mathrm{H}), 3.63-3.72(\mathrm{~m}, 6 \mathrm{H}), 3.54(\mathrm{~m}, 2 \mathrm{H}), 3.37\left(\mathrm{~s}, 3 \mathrm{H}, \mathrm{OCH}_{3}\right) 2.04(\mathrm{~s}, 6 \mathrm{H}, \mathrm{C} \equiv$ $\left.\mathrm{CCH}_{3}\right) ;{ }^{13} \mathrm{C} \mathrm{NMR}\left(\mathrm{CDCl}_{3}, 100 \mathrm{MHz}\right): \delta 165.4,138.3,131.6,130.4,124.6,87.3$ (Ar-C $\equiv$ C), 78.2 (Ar- $C \equiv \mathrm{C}), 71.9,70.7,70.6,70.5,69.1,64.3,59.0,4.3\left(\mathrm{C} \equiv \mathrm{CCH}_{3}\right)$; LR-MS (EI): m/z (\%): 344.2 (23), 225.1 (68), 198.1 (40), 181.1 (100), 153.1 (42), 84.0 (98); HR-MS $\left(\mathrm{C}_{20} \mathrm{H}_{24} \mathrm{O}_{5}\right)$ : calcd 344.1624, found 344.1619; TLC R $\mathrm{R}_{f}=0.20$ ( $n$-Hexane/EtOAc, 7/3, v/v); Anal. Calcd for $\mathrm{C}_{20} \mathrm{H}_{24} \mathrm{O}_{5}$ (344.16): C, 69.75; H, 7.02; Found: C, 69.72; H, 7.01.

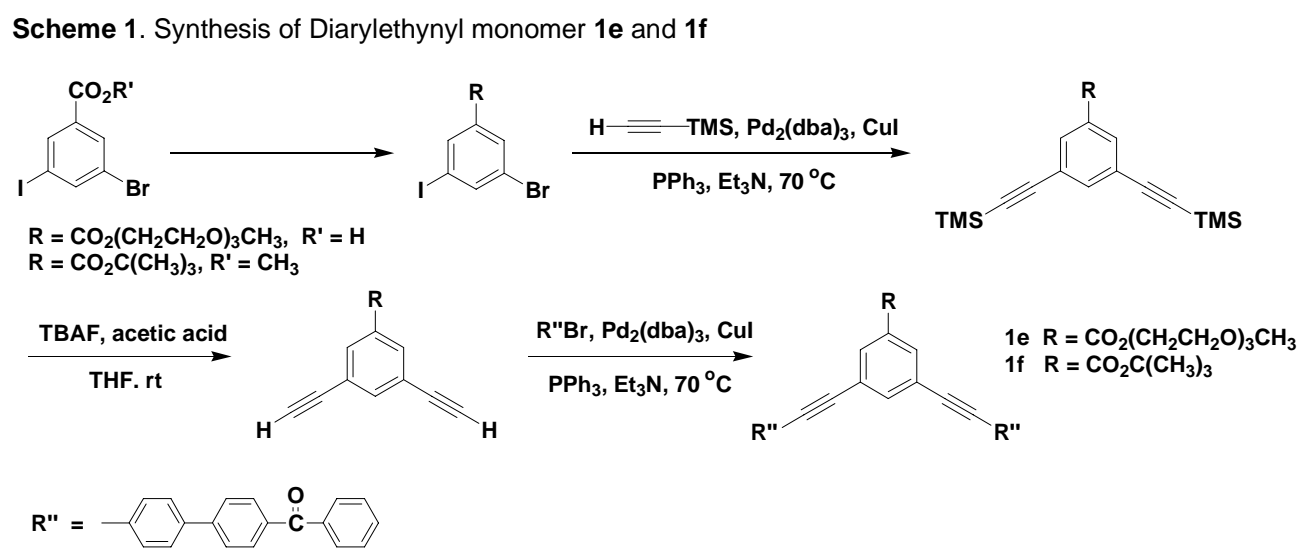

2-[2-(2-Methoxyethoxy) ethoxy] ethyl 3-iodo-5-bromobenzoate: To a $100 \mathrm{~mL}$ roundbottomed flask was added diphenylammonium triflate ${ }^{6}(0.488 \mathrm{~g}, 1.53 \mathrm{mmol}), 3$-iodo-5bromobenzoic acid $(5.00,15.3 \mathrm{mmol})$, tri(ethylene glycol) monomethyl ether $(6.28 \mathrm{~g}$, $38.2 \mathrm{mmol}$ ) and toluene $(50 \mathrm{~mL})$. The resulting solution was heated to reflux for $18 \mathrm{~h}$. After removing the solvent in vacuo, the residue was purified by column chromatography ( $n$-Hexane/EtOAc, $2 / 1, \mathrm{v} / \mathrm{v})$ affording the product as a yellow oil $(6.51 \mathrm{~g}, 90 \%)$. The spectroscopic ${ }^{1} \mathrm{H}$ and ${ }^{13} \mathrm{C}$ NMR data are in agreement with those reported in the literature. $^{7}$ 
t-Butyl 3-iodo-5-bromobenzoate ${ }^{8}$ : A solution of $n$-butyllithium in hexane (11.6 mL, 1.6 M) was added dropwise to $t-\mathrm{BuOH}(4.5 \mathrm{~mL}, 47 \mathrm{mmol})$ and stirred for $20 \mathrm{~min}$. This mixture was added dropwise to a solution of methyl 3-iodo-5-bromobenzoate (3.0 g, 8.8 mmol) in THF $(6 \mathrm{~mL})$. The reaction mixture was allowed to stir overnight $(18 \mathrm{~h})$ at room temperature. The solvents were removed under reduced pressure and saturated ammonium chloride solution $\left(50 \mathrm{~mL}\right.$ in $\left.\mathrm{H}_{2} \mathrm{O}\right)$ was added. The product was extracted with ether $(3 \times 60 \mathrm{~mL})$, washed with brine and concentrated in vacuo to yield a yellow oil (3.3 g, 98\%). $\left.{ }^{1} \mathrm{H} \mathrm{NMR} \mathrm{(CDCl} 3,400 \mathrm{MHz}\right): \delta 8.22(\mathrm{t}, J=1.4 \mathrm{~Hz}, 1 \mathrm{H}, \mathrm{ArH}), 8.05(\mathrm{t}, J=1.4$ $\mathrm{Hz}, 1 \mathrm{H}, \mathrm{ArH}), 7.99(\mathrm{t}, J=1.4 \mathrm{~Hz}, 1 \mathrm{H}, \mathrm{ArH}), 1.58\left[\mathrm{~s}, 9 \mathrm{H}, \mathrm{C}\left(\mathrm{CH}_{3}\right)_{3}\right] ;{ }^{13} \mathrm{C} \mathrm{NMR}\left(\mathrm{CDCl}_{3}\right.$, $100 \mathrm{MHz}): \delta 162.8,143.2,137.0,135.1,131.8,122.8,93.9,82.4\left[\mathrm{C}\left(\mathrm{CH}_{3}\right)_{3}\right], 28.0$ [C $\left.\left(\mathrm{CH}_{3}\right)_{3}\right] ;$ LR-MS (EI): m/z (\%): 384.2 (20), 326.1 (55), 309.1 (28), 281.1 (8), 154.1 (12), 75.1 (31); HR-MS $\left(\mathrm{C}_{11} \mathrm{H}_{12} \mathrm{O}_{2} \mathrm{IBr}\right)$ : calcd 381.9065, found 381.9066.

\section{2-[2-(2-Methoxyethoxy) ethoxy] ethyl 3,5-di(trimethylsilylethynyl)benzoate:}

Application of Sonogashira's general procedure for alkyne coupling ${ }^{9}\{2-[2-(2-$ methoxyethoxy) ethoxy] ethyl 3-iodo-5-bromobenzoate $\left(\begin{array}{lllll}6.00 & \mathrm{~g}, & 12.7 & \mathrm{mmol}\end{array}\right)$, trimethylsilylacetylene ( $4.36 \mathrm{~g}, 44.4 \mathrm{mmol}), \mathrm{Pd}_{2}(\mathrm{dba})_{3}(0.70 \mathrm{~g}, 0.76 \mathrm{mmol}), \mathrm{CuI}(0.241 \mathrm{~g}$, $1.27 \mathrm{mmol})$ and $\mathrm{PPh}_{3}(1.34 \mathrm{~g}, 5.07 \mathrm{mmol})$ in triethylamine $\left.(60 \mathrm{~mL})\right\}$ gave the product as a yellow oil (5.74 g, 98\%). ${ }^{1} \mathrm{H}$ and ${ }^{13} \mathrm{C}$ NMR spectroscopic data are in agreement with those reported in the literature. ${ }^{10}$

t-Butyl 3,5-di(trimethylsilylethynyl)benzoate: Application of Sonogashira's general procedure for alkyne coupling ${ }^{9}$ [t-butyl 3-iodo-5-bromobenzoate $(3.00 \mathrm{~g}, 7.83 \mathrm{mmol})$, trimethylsilylacetylene (2.69 g, $27.4 \mathrm{mmol}), \mathrm{Pd}_{2}(\mathrm{dba})_{3}(0.43 \mathrm{~g}, 0.47 \mathrm{mmol}), \mathrm{CuI}(0.149 \mathrm{~g}$, $0.78 \mathrm{mmol})$ and $\mathrm{PPh}_{3}(0.826 \mathrm{~g}, 3.13 \mathrm{mmol})$ in triethylamine $\left.(40 \mathrm{~mL})\right]$ gave the product as 
a yellow oil (2.86 g, 99\%). ${ }^{1} \mathrm{H}$ NMR $\left(\mathrm{CDCl}_{3}, 500 \mathrm{MHz}\right): \delta 7.97$ (d, $\left.J=1.6 \mathrm{~Hz}, 2 \mathrm{H}, \mathrm{Ar} H\right)$, $7.70(\mathrm{t}, J=1.6 \mathrm{~Hz}, 1 \mathrm{H}, \mathrm{ArH}), 1.58\left[\mathrm{~s}, 9 \mathrm{H}, \mathrm{C}\left(\mathrm{CH}_{3}\right)_{3}\right], 0.24\left[\mathrm{~s}, 18 \mathrm{H}, \mathrm{Si}\left(\mathrm{CH}_{3}\right)_{3}\right] ;{ }^{13} \mathrm{C} \mathrm{NMR}$ $\left(\mathrm{CDCl}_{3}, 125 \mathrm{MHz}\right): \delta 164.3,138.6,132.5,132.4,123.6,103.2(\mathrm{Ar}-\mathrm{C} \equiv C), 95.8(\mathrm{Ar}-\mathrm{C} \equiv$ C), $81.7\left[C\left(\mathrm{CH}_{3}\right)_{3}\right], 28.1\left[\mathrm{C}\left(\mathrm{CH}_{3}\right)_{3}\right],-0.2\left[\mathrm{Si}\left(\mathrm{CH}_{3}\right)_{3}\right] ; \mathrm{LR}-\mathrm{MS}(\mathrm{EI}): \mathrm{m} / \mathrm{z}(\%): 370.2(53)$, 355.2 (49), 314.1 (15), 299.1 (100), 170.1 (7), 142.1 (22); HR-MS $\left(\mathrm{C}_{21} \mathrm{H}_{30} \mathrm{Si}_{2} \mathrm{O}_{2}\right)$ : calcd 370.1784 , found 370.1784 .

2-[2-(2-Methoxyethoxy) ethoxy] ethyl 3,5-diethynylbenzoate: To a solution of 2-[2-(2methoxyethoxy) ethoxy] ethyl 3,5-di(trimethylsilylethynyl)benzoate (2.00 g, $4.35 \mathrm{mmol})$ in THF $(150 \mathrm{~mL})$ was added a solution of tetrabutylammonium fluoride (TBAF) in THF $(9.6 \mathrm{~mL}, 1.0 \mathrm{M})$ and glacial acetic acid $(0.53 \mathrm{~mL}, 9.6 \mathrm{mmol})$. The solution was stirred for $5 \mathrm{~min}$ at $\mathrm{rt}$, and the solvent was removed in vacuo to leave a brown residue. The residue was purified by silica gel column chromatography $(n-H e x a n e / E t O A c, 6 / 4, v / v)$ to give the product as a light yellow oil (1.23 g, 89\%). The spectroscopic ${ }^{1} \mathrm{H}$ and ${ }^{13} \mathrm{C}$ NMR data are in agreement with those reported in the literature. ${ }^{10}$

t-Butyl 3,5-diethynylbenzoate: Application of the desilylation procedure as for preparation of 2-[2-(2-methoxyethoxy) ethoxy] ethyl 3,5-diethynylbenzoate [t-butyl 3,5di(trimethylsilylethynyl)benzoate $(2.86 \mathrm{~g}, 7.73 \mathrm{mmol})$, tetrabutylammonium fluoride (TBAF) $(17.0 \mathrm{~mL}, 1.0 \mathrm{M})$ and glacial acetic acid $(0.93 \mathrm{~mL}, 17.0 \mathrm{mmol})$ in THF (200 $\mathrm{mL})$ ] gave the product as a light yellow oil $(1.63 \mathrm{~g}, 93 \%) .{ }^{1} \mathrm{H} \mathrm{NMR}\left(\mathrm{CDCl}_{3}, 400 \mathrm{MHz}\right)$ : $\delta 8.05(\mathrm{~d}, J=1.5 \mathrm{~Hz}, 2 \mathrm{H}, \operatorname{ArH}), 7.73(\mathrm{t}, J=1.5 \mathrm{~Hz}, 1 \mathrm{H}, \operatorname{ArH}), 3.12(\mathrm{~s}, 2 \mathrm{H}, \mathrm{C} \equiv \mathrm{CH}), 1.59$ $\left[\mathrm{s}, 9 \mathrm{H}, \mathrm{C}\left(\mathrm{CH}_{3}\right)_{3}\right] ;{ }^{13} \mathrm{C} \mathrm{NMR}\left(\mathrm{CDCl}_{3}, 100 \mathrm{MHz}\right): \delta 164.0,138.8,133.1,132.6,122.7,81.9$ $(\mathrm{Ar}-\mathrm{C} \equiv \mathrm{C}), 81.8\left[\mathrm{C}\left(\mathrm{CH}_{3}\right)_{3}\right], 78.6(\mathrm{Ar}-\mathrm{C} \equiv \mathrm{C}), 28.1\left[\mathrm{C}\left(\mathrm{CH}_{3}\right)_{3}\right] ; \mathrm{LR}-\mathrm{MS}(\mathrm{EI}): \mathrm{m} / \mathrm{z}(\%)$ : 
226.1 (27), 196.1 (48), 181.1 (13), 170.1 (83), 153.1 (100), 125.1 (40); HR-MS $\left(\mathrm{C}_{15} \mathrm{H}_{14} \mathrm{O}_{2}\right)$ : calcd 226.0994, found 226.0994.

2-[2-(2-Methoxyethoxy) ethoxy] ethyl 3,5-di(benzoylbiphenylethynyl)benzoate (1e): Application of Sonogashira's general procedure for alkyne coupling ${ }^{9}$ [2-[2-(2methoxyethoxy) ethoxy] ethyl 3,5-diethynylbenzoate ( $0.600 \mathrm{~g}, 1.90 \mathrm{mmol})$, 4-benzoyl4'-bromobiphenyl (1.92 g, $5.70 \mathrm{mmol}), \mathrm{Pd}_{2}(\mathrm{dba})_{3}(0.11 \mathrm{~g}, 0.11 \mathrm{mmol}), \mathrm{CuI}(0.036 \mathrm{~g}, 0.19$ mmol $)$ and $\mathrm{PPh}_{3}(0.20 \mathrm{~g}, 0.76 \mathrm{mmol})$ in triethylamine $(5 \mathrm{~mL})$ and DMF $\left.(8 \mathrm{~mL})\right]$ gave the product as a yellow solid $(1.08 \mathrm{~g}, 68 \%) .{ }^{1} \mathrm{H}$ NMR $\left(\mathrm{CDCl}_{3}, 500 \mathrm{MHz}\right): \delta 8.20(\mathrm{~d}, J=1.4$ Hz, 2H, ArH), 7.90-7.94 (m, 5H, ArH), $7.84(\mathrm{~d}, J=8.0 \mathrm{~Hz}, 4 \mathrm{H}, \operatorname{ArH}), 7.73(\mathrm{~d}, J=8.0$ $\mathrm{Hz}, 4 \mathrm{H}, \operatorname{Ar} H), 7.65-7.70(\mathrm{~m}, 8 \mathrm{H}, \operatorname{ArH}), 7.60-7.64(\mathrm{~m}, 2 \mathrm{H}, \operatorname{ArH})$, 7.50-7.54 (m, 4H, ArH), $4.53(\mathrm{~m}, 2 \mathrm{H}), 3.88(\mathrm{~m}, 2 \mathrm{H}), 3.66-3.76(\mathrm{~m}, 6 \mathrm{H}), 3.55(\mathrm{~m}, 2 \mathrm{H}), 3.36\left(\mathrm{~s}, 3 \mathrm{H}, \mathrm{OCH}_{3}\right) ;{ }^{13} \mathrm{C}$ NMR $\left(\mathrm{CDCl}_{3}, 125 \mathrm{MHz}\right): \delta 196.3$ (ArCOAr), 165.3 (ArCOO), 144.1, 140.2, 138.3, $137.6,136.6,132.5,132.4,132.3,130.9,130.8,130.0,128.3,127.3,126.9,124.1,122.5$, $90.6(\operatorname{Ar}-\mathrm{C} \equiv C), 88.8(\mathrm{Ar}-C \equiv \mathrm{C}), 71.9,70.7,70.6,69.1,64.5,59.0 ; \quad$ LR-MS (EI): $\mathrm{m} / \mathrm{z}$ (\%): 828.5 (12), 648.3 (7), 538.2 (8), 336.1 (13), 244.1 (27), 181.1 (25), 129.1 (40); HRMS $\left(\mathrm{C}_{56} \mathrm{H}_{44} \mathrm{O}_{7}\right)$ : calcd 828.3087, found 828.3082; TLC $\mathrm{R}_{f}=0.17$ (n-Hexane/EtOAc, 3/2); Anal. Calcd for $\mathrm{C}_{56} \mathrm{H}_{44} \mathrm{O}_{7}$ (828.31): C, 81.14; H, 5.35; Found: C, 80.79; H, 5.38 .

t-Butyl 3,5-di(benzoylbiphenylethynyl)benzoate (1f): Application of Sonogashira's general procedure for alkyne coupling ${ }^{9}$ [t-butyl 3,5-diethynylbenzoate $(1.49 \mathrm{~g}, 6.60$ mmol), 4-benzoyl-4'-bromobiphenyl (4.89 g, $14.5 \mathrm{mmol}), \mathrm{Pd}_{2}(\mathrm{dba})_{3}(0.365 \mathrm{~g}, 0.40$ mmol), $\mathrm{CuI}(0.125 \mathrm{~g}, 0.66 \mathrm{mmol})$ and $\mathrm{PPh}_{3}(0.696 \mathrm{~g}, 2.64 \mathrm{mmol})$ in triethylamine (17 $\mathrm{mL})$ and DMF $(32 \mathrm{~mL})$ ] gave the product as a yellow solid $(3.52 \mathrm{~g}, 72 \%) .{ }^{1} \mathrm{H}$ NMR $\left(\mathrm{CDCl}_{3}, 400 \mathrm{MHz}\right): \delta 8.12(\mathrm{~d}, J=1.5 \mathrm{~Hz}, 2 \mathrm{H}, \mathrm{ArH}), 7.92(\mathrm{~d}, J=8.2 \mathrm{~Hz}, 4 \mathrm{H}, \operatorname{Ar} H), 7.89$ 
(t, $J=1.5 \mathrm{~Hz}, 1 \mathrm{H}, \operatorname{ArH}), 7.84(\mathrm{~d}, J=8.1 \mathrm{~Hz}, 4 \mathrm{H}, \operatorname{ArH}), 7.74(\mathrm{~d}, J=8.1 \mathrm{~Hz}, 4 \mathrm{H}, \operatorname{Ar} H)$, 7.65-7.70 (m, 8H, ArH), 7.59-7.64 (m, 2H, ArH), 7.49-7.54 (m, 4H, ArH), 1.64 [s, 9H, $\left.\mathrm{C}\left(\mathrm{CH}_{3}\right)_{3}\right] ;{ }^{13} \mathrm{C} \mathrm{NMR}\left(\mathrm{CDCl}_{3}, 100 \mathrm{MHz}\right): \delta 196.2$ (ArCOAr), 164.3 (ArCOO), 144.1, $140.1,137.8,137.6,136.6,132.7,132.5,132.3,132.2,130.8,130.0,128.3,127.3,126.9$, 123.8, 122.6, 90.3 (Ar-C $\equiv C), 89.0(\mathrm{Ar}-\mathrm{C} \equiv \mathrm{C}), 81.9\left[C\left(\mathrm{CH}_{3}\right)_{3}\right], 28.2\left[\mathrm{C}\left(\mathrm{CH}_{3}\right)_{3}\right]$; LR-MS (ESI): $[\mathrm{M}+\mathrm{H}]^{+}$calcd 739.2, found 739.1; HR-MS $\left(\mathrm{C}_{53} \mathrm{H}_{38} \mathrm{O}_{4}\right):[\mathrm{M}+\mathrm{H}]^{+}$calcd 739.2848, found 739.2883 .

Macrocycle (2a): In an argon filled glove box, a solution of molybdenum triamide ${ }^{11}(10.0$ $\mathrm{mg}, 0.015 \mathrm{mmol})$ and $p$-nitrophenol $(6.3 \mathrm{mg}, 0.045 \mathrm{mmol})$ in 1,2,4-trichlorobenzene ( 0.8 $\mathrm{mL}$, anhydrous grade $)^{12}$ was added to a solution of $1 \mathbf{a}(31.5 \mathrm{mg}, 0.15 \mathrm{mmol})$ in $1,2,4-$ trichlorobenzene $(0.4 \mathrm{~mL})$. The flask was sealed and removed from the glove box. The resulting mixture was stirred for $22 \mathrm{~h}$ at $30{ }^{\circ} \mathrm{C}$ under vacuum $(1 \mathrm{~mm} \mathrm{Hg})$. Upon connecting to the vacuum, vigorous gas evolution was observed initially. After removing the solvent under high vacuum, the residue was purified by column chromatography $\left(\mathrm{CH}_{2} \mathrm{Cl}_{2} / \mathrm{n}\right.$-Hexane, $1 / 9$, v/v) yielding macrocycle $2 \mathrm{a}$ as a white solid $(14.3 \mathrm{mg}, 61 \%)$. The cyclic hexamer and cyclic pentamer were observed by FD-MS. The molar ratio of cyclic hexamer to pentamer is estimated to be $6: 1$ based on ${ }^{1} \mathrm{H}$ NMR integration. The spectroscopic ${ }^{1} \mathrm{H},{ }^{13} \mathrm{C}$ NMR and FD-MS data for the cyclic hexamer are in agreement with those reported in the literature. ${ }^{13}$

Macrocycle (2b): Application of the procedure as for the preparation of 2a [1 $\mathbf{1 b}(47.4 \mathrm{mg}$, $0.15 \mathrm{mmol})$, molybdenum triamide $(10.0 \mathrm{mg}, 0.015 \mathrm{mmol})$ and $p$-nitrophenol $(6.3 \mathrm{mg}$, $0.045 \mathrm{mmol})$ in $1,2,4$-trichlorobenzene $(1.2 \mathrm{~mL})$ ] gave the product $\mathbf{2 b}$ as a yellow wax (26.6 mg, 68\%). Both the cyclic hexamer and cyclic pentamer were observed by MALDI- 
MS but they could not be resolved by ${ }^{1} \mathrm{H}$ NMR. The spectroscopic ${ }^{1} \mathrm{H},{ }^{13} \mathrm{C}$ NMR and MALDI-MS data for the cyclic hexamer are in agreement with those reported in the literature. $^{14}$

Macrocycle (2c): Application of the procedure as for the preparation of 2a [1c (49.5 mg, $0.15 \mathrm{mmol})$, molybdenum triamide $(10.0 \mathrm{mg}, 0.015 \mathrm{mmol})$ and $p$-nitrophenol $(6.3 \mathrm{mg}$, $0.045 \mathrm{mmol})$ in $1,2,4$-trichlorobenzene $(1.2 \mathrm{~mL})$ ] gave the product $2 \mathrm{c}$ as a yellow wax (26.9 mg, 65\%). The cyclic hexamer and cyclic pentamer were observed by MALDI-MS. The molar ratio of cyclic hexamer to pentamer is estimated to be $8: 1$ based on ${ }^{1} \mathrm{H}$ NMR integration. The spectroscopic ${ }^{1} \mathrm{H},{ }^{13} \mathrm{C}$ and MALDI-MS data for the cyclic hexamer are in agreement with those reported in the literature. ${ }^{14}$

Macrocycle (2d) using vacuum driven condition: Application of the procedure as for the preparation of $\mathbf{2 a}$ [ $\mathbf{1 d}(51.6 \mathrm{mg}, 0.15 \mathrm{mmol})$, molybdenum triamide $(10.0 \mathrm{mg}, 0.015$ mmol) and p-nitrophenol (6.3 $\mathrm{mg}, 0.045 \mathrm{mmol})$ in 1,2,4-trichlorobenzene $(1.2 \mathrm{~mL})]$ gave the product $\mathbf{2 d}$ as a yellow wax $(33 \mathrm{mg}, 76 \%)$. The hexacycle product was purified by column chromatography $\left(i-\mathrm{PrOH} / \mathrm{CH}_{2} \mathrm{Cl}_{2}, 1 / 11, \mathrm{v} / \mathrm{v}\right)$. The mass ratio of silica gel 62 to crude product is $150: 1$. The hexacycle product was obtained cleanly with no pentacycle or polymer observed by MALDI-MS and ${ }^{1} \mathrm{H}$ NMR. ${ }^{1} \mathrm{H}$ NMR $\left(\mathrm{CDCl}_{3}, 500 \mathrm{MHz}\right): \delta 8.10$ (d, $J=1.5 \mathrm{~Hz}, 12 \mathrm{H}, \operatorname{ArH}), 7.77(\mathrm{t}, J=1.5 \mathrm{~Hz}, 6 \mathrm{H}, \mathrm{ArH}), 4.53(\mathrm{~m}, 12 \mathrm{H}), 3.90(\mathrm{~m}, 12 \mathrm{H})$, 3.66-3.78 (m, 36H), 3.55 (m, 12H), 3.36 (s, $\left.18 \mathrm{H}, \mathrm{OCH}_{3}\right) ;{ }^{13} \mathrm{C} \mathrm{NMR}\left(\mathrm{CDCl}_{3}, 125 \mathrm{MHz}\right): \delta$ $164.9,138.6,132.5,131.1,123.5,89.1$ (Ar- $C \equiv C-A r), 71.9,70.7,70.6,70.5,69.0,64.5$, 59.0; MS (MALDI) $\mathrm{m} / \mathrm{z}\left([\mathrm{M}+\mathrm{Na}]^{+}\right) 1764.2$ (calcd 1763.8); TLC $\mathrm{R}_{f}=0.38$ (iPrOH/EtOAc, 1/9, v/v); GPC $1990\left(\mathrm{M}_{\mathrm{n}}\right), 1.00\left(\mathrm{M}_{\mathrm{w}} / \mathrm{M}_{\mathrm{n}}\right)$. 


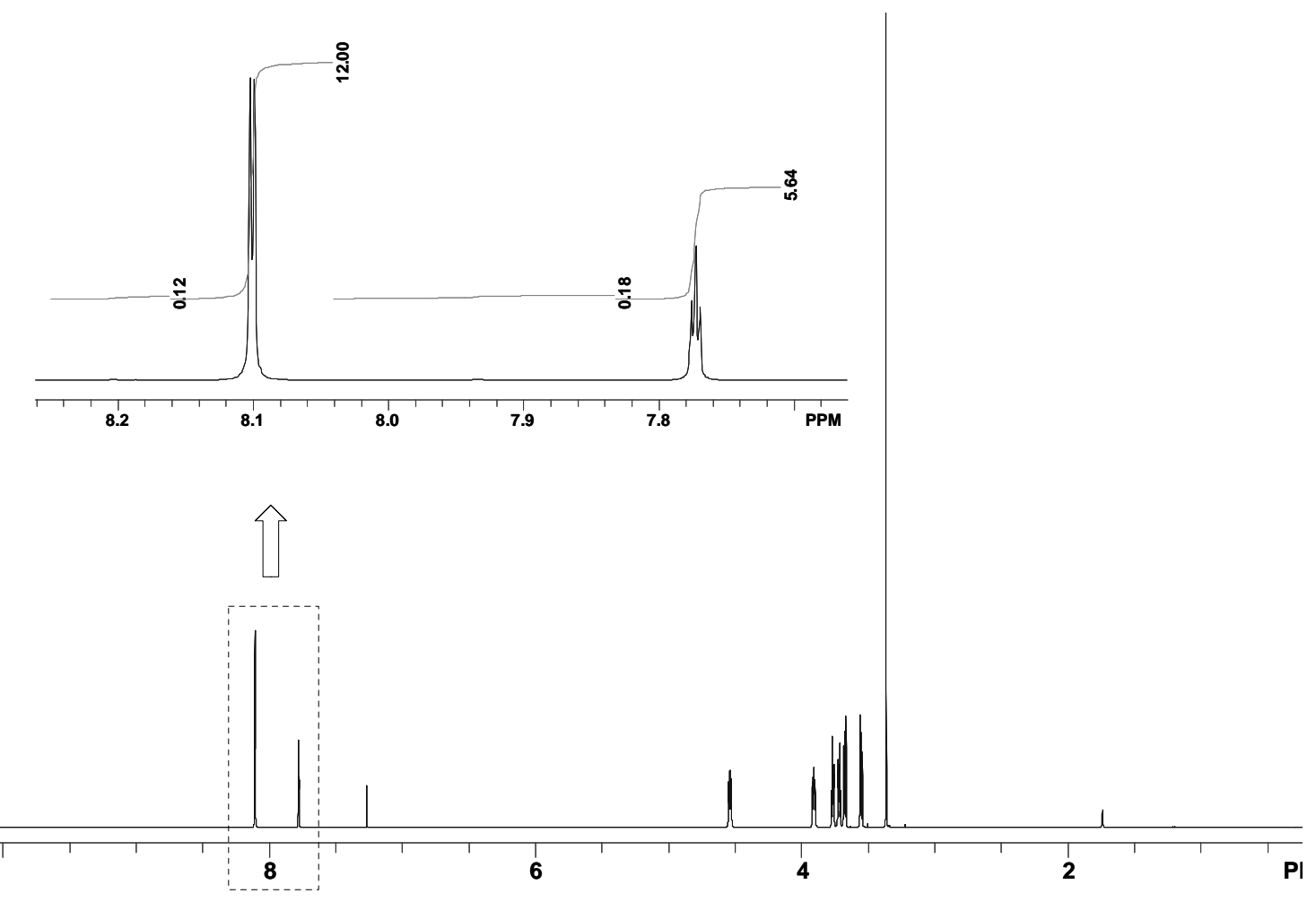

${ }^{1} \mathrm{H}$ NMR spectrum of purified macrocycle $2 \mathbf{d}\left(\mathrm{CDCl}_{3}, 500 \mathrm{MHz}, 2{ }^{\circ} \mathrm{C}\right)$

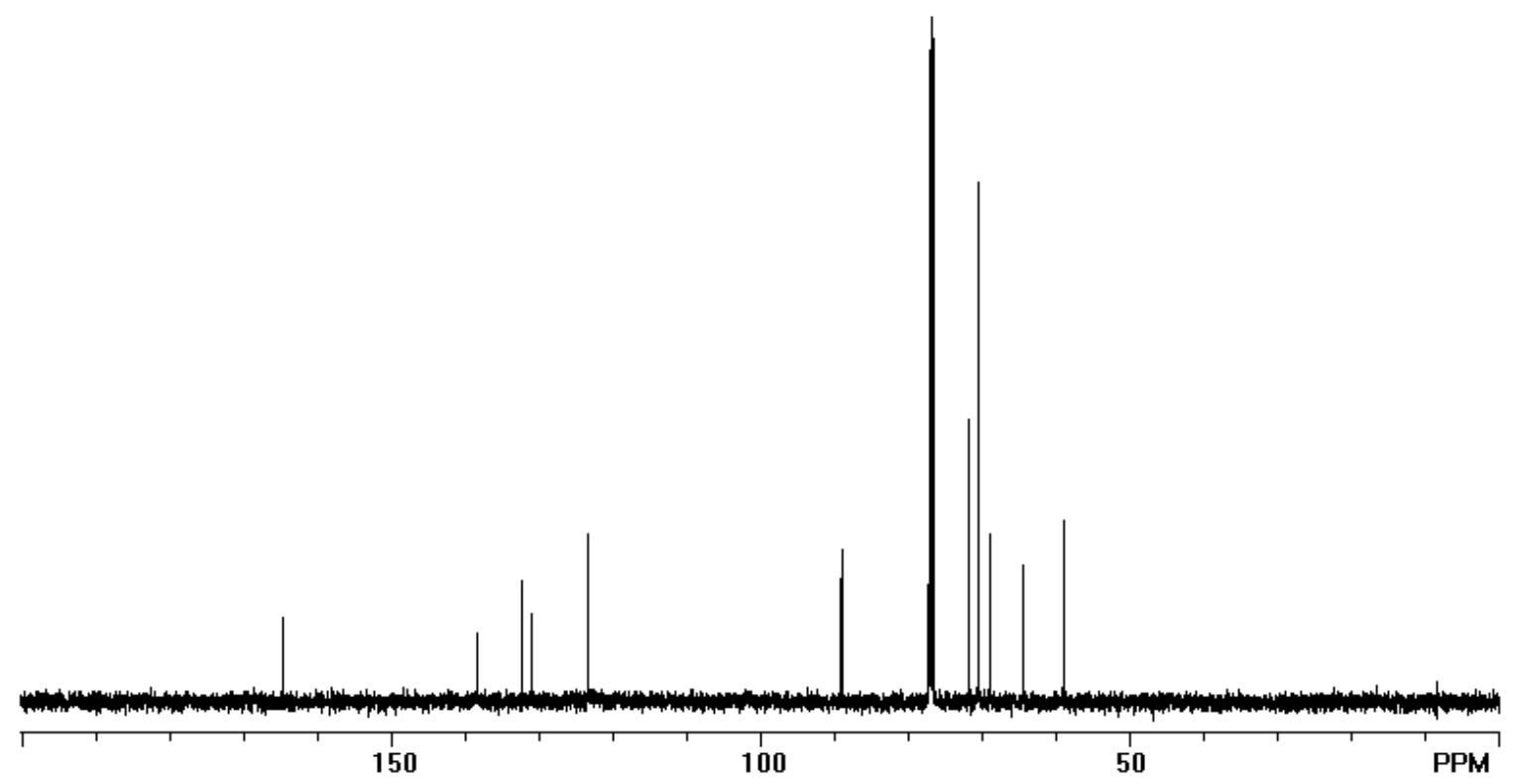

${ }^{13} \mathrm{C}$ NMR spectrum of purified macrocycle $2 \mathbf{d}\left(\mathrm{CDCl}_{3}, 125 \mathrm{MHz}, 20^{\circ} \mathrm{C}\right)$ 


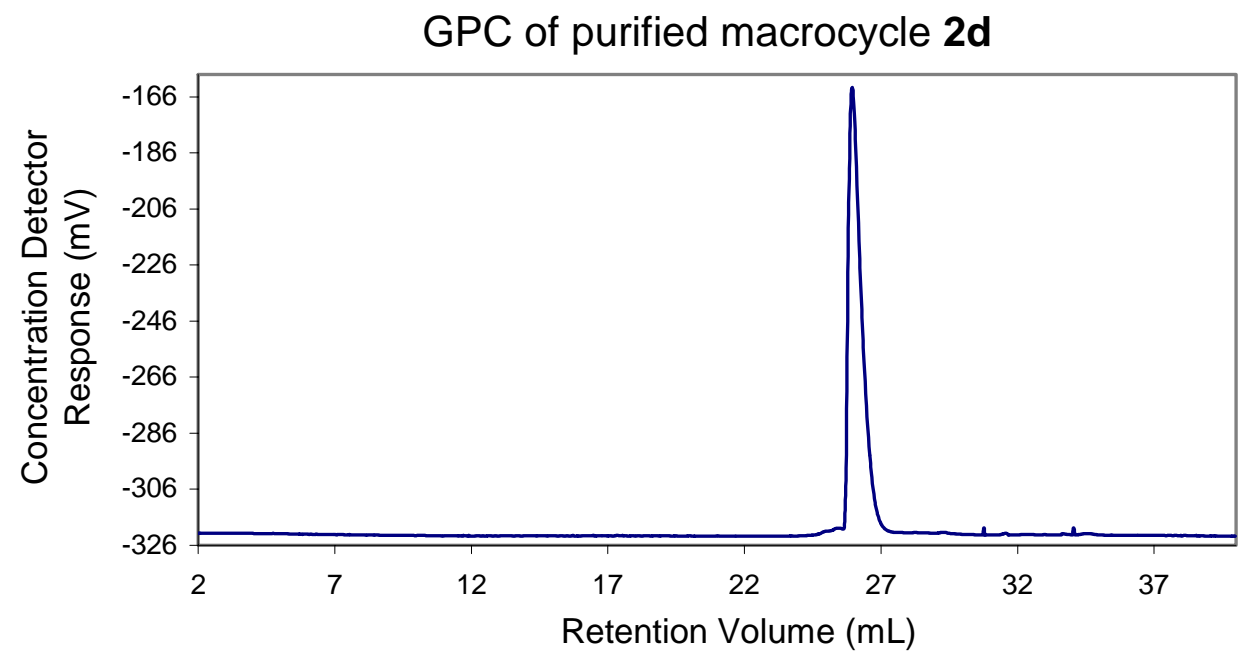

Macrocycle (2e) using precipitation-driven conditions for large-scale synthesis: In an argon filled glove box, a solution of molybdenum triamide (1.69 g, $2.54 \mathrm{mmol})$ and $p$ nitrophenol $(1.06 \mathrm{~g}, 7.61 \mathrm{mmol})$ in $\mathrm{CCl}_{4}(200 \mathrm{~mL})$ was added to a solution of $1 \mathrm{e}(21.0 \mathrm{~g}$, $25.4 \mathrm{mmol})$ in $\mathrm{CCl}_{4}(500 \mathrm{~mL}$ in $1.0 \mathrm{~L}$ round-bottomed flask). The flask was sealed and removed from the glove box. The resulting mixture was stirred for $22 \mathrm{~h}$ at $30^{\circ} \mathrm{C}$. The precipitated byproduct formed almost immediately upon warming to $30{ }^{\circ} \mathrm{C}$. After filtration to remove the precipitate, the filtrate was concentrated in vacuo and the residue was purified by column chromatography $\left(i-\mathrm{PrOH} / \mathrm{CH}_{2} \mathrm{Cl}_{2}, 1 / 9\right.$, v/v) to give macrocycle 2e (5.68 g, 77\%) as a yellow wax. The major impurity is cyclic pentamer, ${ }^{15}$ and the molar ratio of cyclic hexamer to pentamer is estimated to be 9:1 based on ${ }^{1} \mathrm{H}$ NMR integration. The cyclic pentamer can be separated from the macrocyclic product by carefully performed chromatography as in the case of 2d. ${ }^{1} \mathrm{H} \mathrm{NMR}\left(\mathrm{CDCl}_{3}, 500 \mathrm{MHz}\right): \delta 8.13(\mathrm{~d}, J$ $=1.5 \mathrm{~Hz}, 12 \mathrm{H}, \operatorname{ArH}), 7.80(\mathrm{t}, J=1.5 \mathrm{~Hz}, 6 \mathrm{H}, \operatorname{ArH}), 4.54(\mathrm{~m}, 12 \mathrm{H}), 3.90(\mathrm{~m}, 12 \mathrm{H}), 3.66-$ $3.78(\mathrm{~m}, 36 \mathrm{H}), 3.55(\mathrm{~m}, 12 \mathrm{H}), 3.36\left(\mathrm{~s}, 18 \mathrm{H}, \mathrm{OCH}_{3}\right) ;{ }^{13} \mathrm{C} \mathrm{NMR}\left(\mathrm{CDCl}_{3}, 125 \mathrm{MHz}\right): \delta$ $164.9,138.6,132.5,131.0,123.5,89.1$ (Ar- $C \equiv C-A r), 71.9,70.7,70.6,70.5,69.0,64.5$, 
59.0; MS (MALDI) $\mathrm{m} / \mathrm{z}\left([\mathrm{M}+\mathrm{Na}]^{+}\right) 1763.9$ (calcd 1763.8); TLC $\mathrm{R}_{f}=0.38$ (i-

$\operatorname{PrOH} /$ EtOAc, 1/9, v/v); GPC $1870\left(\mathrm{M}_{\mathrm{n}}\right), 1.01\left(\mathrm{M}_{\mathrm{w}} / \mathrm{M}_{\mathrm{n}}\right)$.

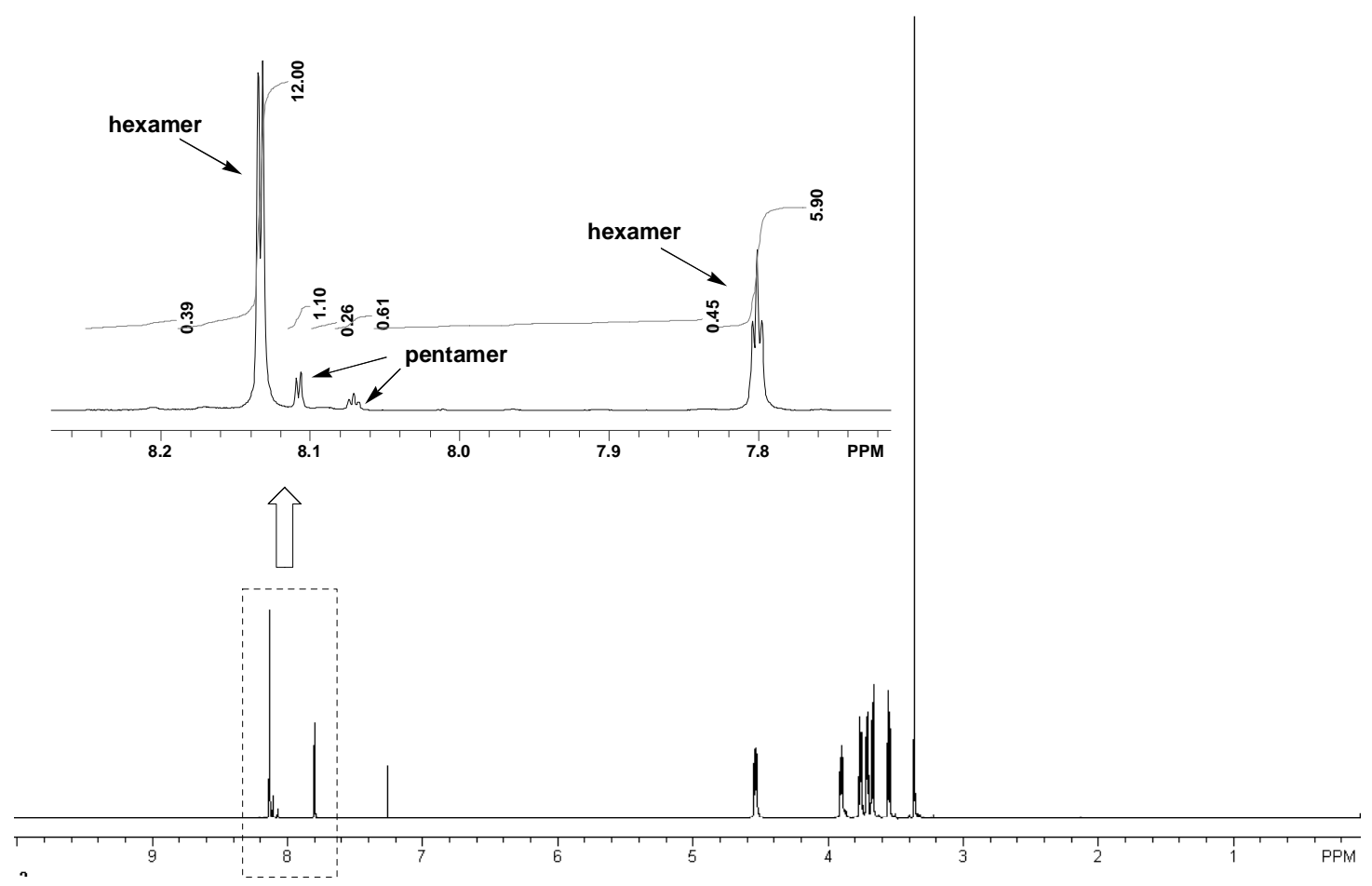

${ }^{1} \mathrm{H}$ NMR spectrum of macrocycle $2 \mathbf{e}\left(\mathrm{CDCl}_{3}, 500 \mathrm{MHz}, 20^{\circ} \mathrm{C}\right)$

This spectrum was recorded on a sample that had not been purified to remove the cyclic pentamer

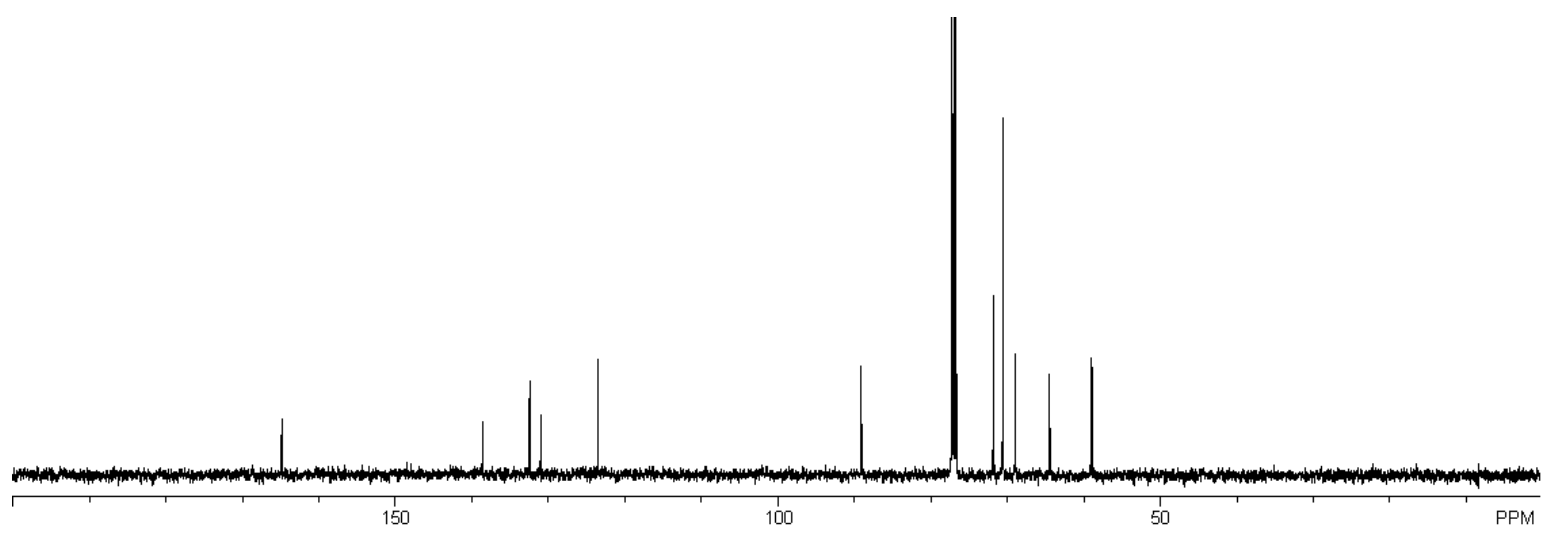

${ }^{13} \mathrm{C}$ NMR spectrum of macrocycle $2 \mathbf{e}\left(\mathrm{CDCl}_{3}, 125 \mathrm{MHz}, 20^{\circ} \mathrm{C}\right)$

This spectrum was recorded on a sample that had not been purified to remove the cyclic pentamer 
GPC of macrocycle $2 \mathrm{e}$ from large-scale synthesis

(No attempt was made to remove the cyclic pentamer)

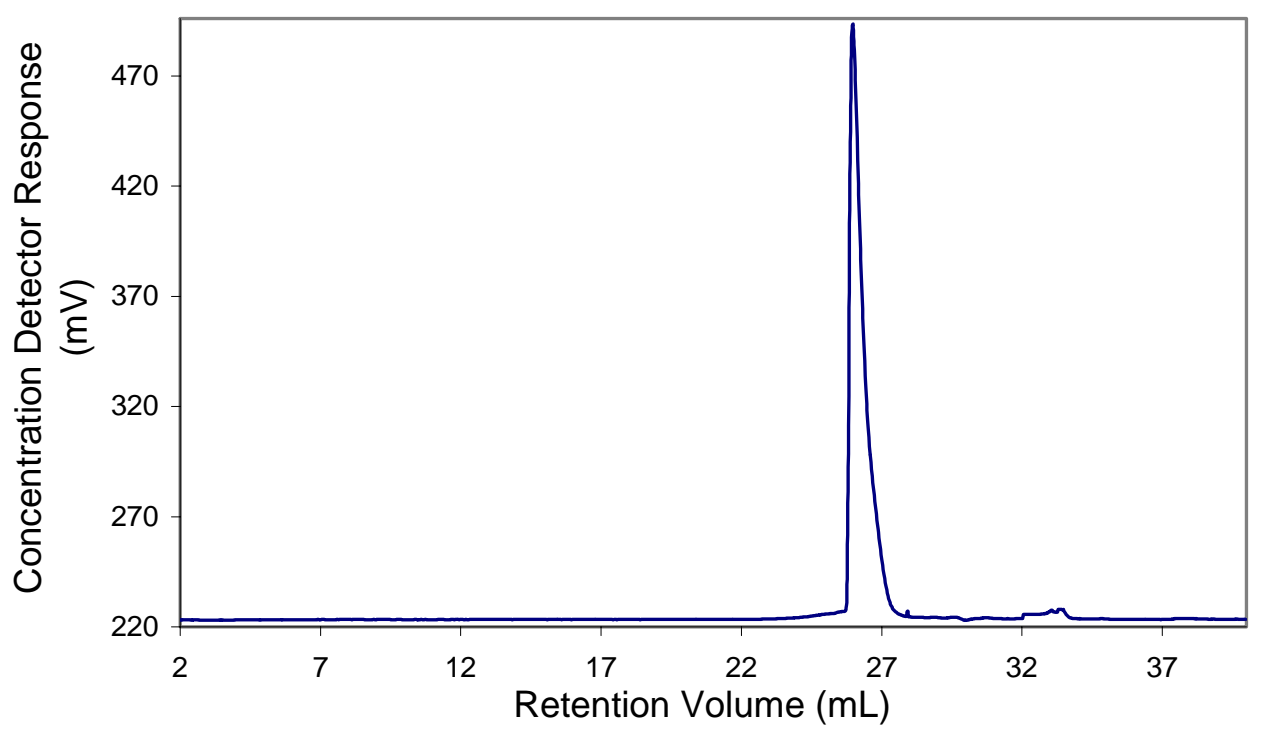

Macrocycle (2f): In an argon filled glove box, a solution of molybdenum triamide $(0.0527 \mathrm{~g}, 0.079 \mathrm{mmol})$ and $p$-nitrophenol $(0.0330 \mathrm{~g}, 0.237 \mathrm{mmol})$ in $\mathrm{CCl}_{4}(6 \mathrm{~mL})$ was added to a solution of $\mathbf{1 f}(0.581 \mathrm{~g}, 0.79 \mathrm{mmol})$ in $\mathrm{CCl}_{4}(16 \mathrm{~mL})$. The flask was sealed and removed from the glove box. The resulting mixture was stirred for $22 \mathrm{~h}$ at $30{ }^{\circ} \mathrm{C}$. After filtration to remove the precipitate, the filtrate was concentrated in vacuo and the residue was purified by column chromatography (EtOAc/n-Hexane, 1/9, v/v) to give macrocycle 2f as a yellow solid $(0.102 \mathrm{~g}, 79 \%)$. The cyclic hexamer and cyclic pentamer were observed by FAB-MS but they could not be resolved by ${ }^{1} \mathrm{H}$ NMR. The spectroscopic ${ }^{1} \mathrm{H}$, ${ }^{13} \mathrm{C}$ NMR and FAB-MS data for the cyclic hexamer are in agreement with those reported in the literature. ${ }^{16}$ 
Scheme 1. Synthesis of Diarylethynyl monomer 3

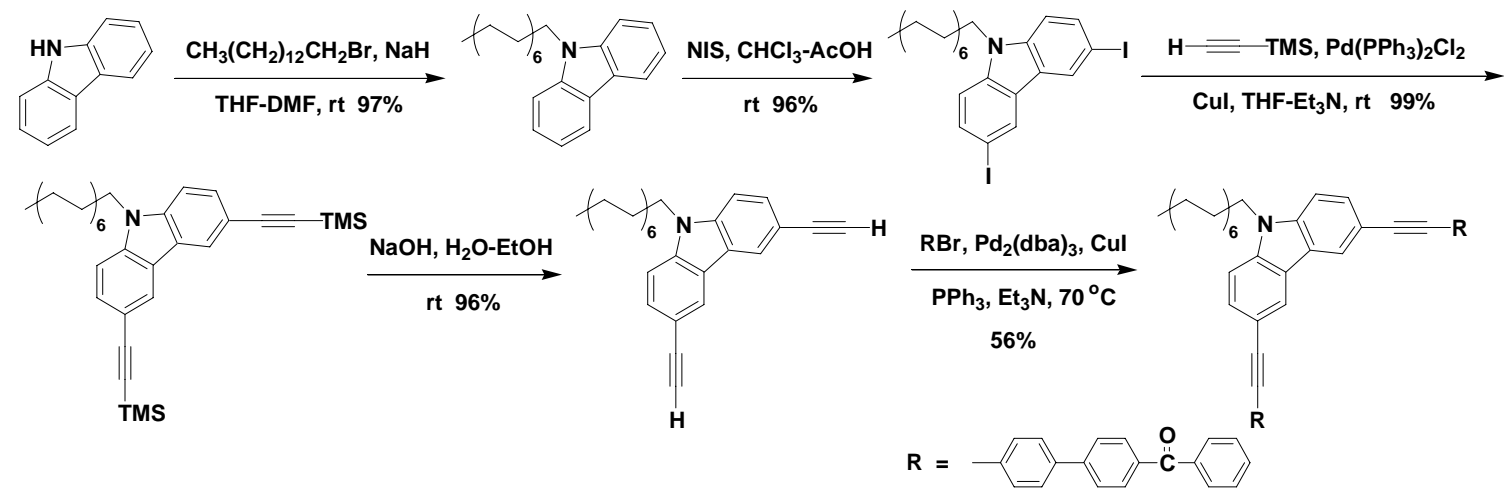

9-Tetradecylcarbazole: To a stirred solution of carbazole $(6.0 \mathrm{~g}, 0.036 \mathrm{~mol})$ in THFDMF $(30 \mathrm{~mL}, 10 \mathrm{~mL})$ was added 1-bromotetradecane $(9.98 \mathrm{~g}, 0.036 \mathrm{~mol})$ at $\mathrm{rt} . \mathrm{NaH}$ (60\% in oil, $2.16 \mathrm{~g}, 0.054 \mathrm{~mol}$ ) was gradually added to the solution and stirred for $1 \mathrm{~h}$. Methanol was added to quench the remaining $\mathrm{NaH}$, and the solvent was evaporated in vacuo. The residue was extracted with $\mathrm{CH}_{2} \mathrm{Cl}_{2}(2 \times 75 \mathrm{~mL})$ and the organic layer was washed with $3 \mathrm{~N}$ aq $\mathrm{HCl}(2 \times 60 \mathrm{~mL}), \mathrm{H}_{2} \mathrm{O}(80 \mathrm{~mL})$, dried with $\mathrm{MgSO}_{4}$ and filtered. The solvent was evaporated in vacuo and purified by column chromatography (hexane only) yielding a white solid (12.68 g, 97\%). ${ }^{1} \mathrm{H} \mathrm{NMR}\left(\mathrm{CDCl}_{3}, 500 \mathrm{MHz}\right): \delta 8.12$ (d, $J=7.8 \mathrm{~Hz}$, 2H, ArH), 7.40-7.49 (m, 4H, ArH), 7.22-7.26 (m, 2H, ArH), $4.30(\mathrm{t}, J=7.0 \mathrm{~Hz}, 2 \mathrm{H}$, $\left.\mathrm{NCH}_{2}\right), 1.88\left(\mathrm{~m}, 2 \mathrm{H}, \mathrm{NCH}_{2} \mathrm{CH}_{2}\right), 1.20-1.42\left(\mathrm{~m}, 22 \mathrm{H}, \mathrm{CH}_{2}\right), 0.90\left(\mathrm{t}, J=6.7 \mathrm{~Hz}, 3 \mathrm{H}, \mathrm{CH}_{3}\right)$; ${ }^{13} \mathrm{C}$ NMR $\left(\mathrm{CDCl}_{3}, 125 \mathrm{MHz}\right): \delta 140.4,125.5,122.8,120.3,118.7,108.6,43.0,31.9$, 29.64, 29.62, 29.57, 29.54, 29.5, 29.4, 29.3, 28.9, 27.3, 22.7, 14.1; LR-MS (EI): m/z (\%): 363.3 (88), 279.1 (4), 180.1 (100), 167.0 (12), 149.0 (15); HR-MS ( $\left.\mathrm{C}_{26} \mathrm{H}_{37} \mathrm{~N}\right)$ : calcd 363.2926, found 363.2924; TLC R $=0.33$ ( $n$-Hexane).

3,6-Diiodo-9-tetradecylcarbazole: A mixture of tetradecyl substituted carbazole $(6.50 \mathrm{~g}$, $17.9 \mathrm{mmol})$ and NIS (8.26 g, $36.7 \mathrm{mmol})$ was stirred in a mixture of $\mathrm{CHCl}_{3}(160 \mathrm{~mL})$ and acetic acid $(50 \mathrm{~mL})$ at $\mathrm{rt}$ under $\mathrm{N}_{2}$ for $16 \mathrm{~h}$. The $\mathrm{CHCl}_{3}$ was evaporated in vacuo and the 
solution was poured into $\mathrm{H}_{2} \mathrm{O}(350 \mathrm{~mL})$. The resulting precipitates were collected and dissolved in $\mathrm{CHCl}_{3}(250 \mathrm{~mL})$. The organic layer was washed with saturated $\mathrm{Na}_{2} \mathrm{SO}_{3}(2 \mathrm{x}$ $100 \mathrm{~mL}), \mathrm{NaCl}(2 \times 100 \mathrm{~mL})$, dried with $\mathrm{MgSO}_{4}$, filtered and concentrated in vacuo. White solids were obtained (10.54 g, 96\%). ${ }^{1} \mathrm{H}$ NMR $\left(\mathrm{CDCl}_{3}, 500 \mathrm{MHz}\right): \delta 8.33(\mathrm{~d}, J=$ $1.7 \mathrm{~Hz}, 2 \mathrm{H}, \operatorname{Ar} H), 7.71(\mathrm{dd}, J=8.7,1.7 \mathrm{~Hz}, 2 \mathrm{H}, \operatorname{Ar} H), 7.17(\mathrm{~d}, J=8.7 \mathrm{~Hz}, 2 \mathrm{H}, \operatorname{Ar} H$ ), $4.20\left(\mathrm{t}, J=7.0 \mathrm{~Hz}, 2 \mathrm{H}, \mathrm{NCH}_{2}\right), 1.81\left(\mathrm{~m}, 2 \mathrm{H}, \mathrm{NCH}_{2} \mathrm{CH}_{2}\right), 1.16-1.34\left(\mathrm{~m}, 22 \mathrm{H}, \mathrm{CH}_{2}\right), 0.88$ (t, $\left.J=6.7 \mathrm{~Hz}, 3 \mathrm{H}, \mathrm{CH}_{3}\right) ;{ }^{13} \mathrm{C} \mathrm{NMR}\left(\mathrm{CDCl}_{3}, 125 \mathrm{MHz}\right): \delta 139.5,134.5,129.3,123.9$, $110.9,81.6,43.2,31.9,29.65,29.63,29.61,29.56,29.51,29.42,29.35,29.3,28.8,27.2$, 22.7, 14.1; LR-MS (EI): m/z (\%): 615.1 (97), 489.2 (18), 361.2 (6), 305.9 (17), 180.0 (15); HR-MS $\left(\mathrm{C}_{26} \mathrm{H}_{35} \mathrm{NI}_{2}\right)$ : calcd 615.0866, found 615.0867.

3,6-Bis[(trimethylsilyl)ethynyl]-9-tetradecylcarbazole: Application of Sonogashira's general procedure for alkyne coupling ${ }^{9}$ [3,6-diiodo-9-tetradecylcarbazole (4.50 g, 7.32 mmol), 1-trimethylsilylacetylene (7.19 g, $73.2 \mathrm{mmol}), \mathrm{Pd}\left(\mathrm{PPh}_{3}\right)_{2} \mathrm{Cl}_{2}(0.21 \mathrm{~g}, 0.29 \mathrm{mmol})$, $\mathrm{CuI}(0.056 \mathrm{~g}, 0.29 \mathrm{mmol})$ in piperidine $(10 \mathrm{~mL})$ and THF $(18 \mathrm{~mL})]$ at room temperature gave the product as a yellow oil $(4.02 \mathrm{~g}, 99 \%) .{ }^{1} \mathrm{H} \mathrm{NMR}\left(\mathrm{CDCl}_{3}, 500 \mathrm{MHz}\right): \delta 8.20$ (d, $J$ $=1.4 \mathrm{~Hz}, 2 \mathrm{H}, \operatorname{Ar} H), 7.57(\mathrm{dd}, J=8.7,1.4 \mathrm{~Hz}, 2 \mathrm{H}, \operatorname{ArH}), 7.30(\mathrm{~d}, J=8.7 \mathrm{~Hz}, 2 \mathrm{H}, \operatorname{Ar} H)$, $4.24\left(\mathrm{t}, J=7.0 \mathrm{~Hz}, 2 \mathrm{H}, \mathrm{NCH}_{2}\right), 1.83\left(\mathrm{~m}, 2 \mathrm{H}, \mathrm{NCH}_{2} \mathrm{CH}_{2}\right), 1.20-1.35\left(\mathrm{~m}, 22 \mathrm{H}, \mathrm{CH}_{2}\right), 0.88$ (t, $\left.J=6.7 \mathrm{~Hz}, 3 \mathrm{H}, \mathrm{CH}_{3}\right), 0.29$ (s, $\left.18 \mathrm{H}, \mathrm{SiCH}_{3}\right) ;{ }^{13} \mathrm{C} \mathrm{NMR}\left(\mathrm{CDCl}_{3}, 125 \mathrm{MHz}\right): \delta 140.5$, 130.0, 124.7, 122.3, 113.7, 108.8, 106.4 ( $\mathrm{ArC} \equiv C), 92.0(\mathrm{ArC} \equiv \mathrm{C}), 43.3,31.9,29.63$, 29.61, 29.59, 29.55, 29.49, 29.43, 29.32, 29.3, 28.9, 27.2, 22.7, 14.1; LR-MS (EI): $\mathrm{m} / \mathrm{z}$ (\%): 555.4 (100), 372.2 (35), 300.1 (4), 171.7 (6), 73.0 (23); HR-MS $\left(\mathrm{C}_{36} \mathrm{H}_{53} \mathrm{NSi}_{2}\right)$ : calcd 555.3717, found 555.3722; TLC $\mathrm{R}_{f}=0.36($ EtOAc/n-Hexane, 1/19, v/v). 
3,6-Diethynyl-9-tetradecylcarbazole: To a solution of 3,6-bis[(trimethylsilyl)ethynyl]9-tetradecylcarbazole $(4.02 \mathrm{~g}, 7.24 \mathrm{mmol})$ in EtOH $(300 \mathrm{~mL})$ was added a solution of $\mathrm{NaOH}(0.580 \mathrm{~g}, 14.5 \mathrm{mmol})$ in $\mathrm{H}_{2} \mathrm{O}(8 \mathrm{~mL})$. After stirring at $\mathrm{rt}$ for $1 \mathrm{~h}$, the solvent was evaporated and the residue was extracted with $\mathrm{CHCl}_{3}(150 \mathrm{~mL})$. The organic layer was washed with $\mathrm{H}_{2} \mathrm{O}(2 \times 80 \mathrm{~mL})$ and dried $\left(\mathrm{MgSO}_{4}\right)$. The solvent was evaporated in vacuo and the crude product was purified by column chromatography (hexane/EtOAc, 20/1, $\mathrm{v} / \mathrm{v})$ to give the product as a yellow oil $(2.85 \mathrm{~g}, 96 \%) .{ }^{1} \mathrm{H} \mathrm{NMR}\left(\mathrm{CDCl}_{3}, 500 \mathrm{MHz}\right): \delta$ $8.22(\mathrm{~d}, J=1.4 \mathrm{~Hz}, 2 \mathrm{H}, \mathrm{ArH}), 7.60(\mathrm{dd}, J=8.7,1.4 \mathrm{~Hz}, 2 \mathrm{H}, \operatorname{ArH}), 7.33(\mathrm{~d}, J=8.7 \mathrm{~Hz}$, $2 \mathrm{H}, \mathrm{ArH}), 4.26\left(\mathrm{t}, J=7.0 \mathrm{~Hz}, 2 \mathrm{H}, \mathrm{NCH}_{2}\right), 3.08(\mathrm{~s}, 2 \mathrm{H}, \mathrm{C} \equiv \mathrm{CH}), 1.84\left(\mathrm{~m}, 2 \mathrm{H}, \mathrm{NCH}_{2} \mathrm{CH}_{2}\right)$, 1.20-1.36 (m, 22H, $\left.\mathrm{CH}_{2}\right), 0.88\left(\mathrm{t}, J=6.7 \mathrm{~Hz}, 3 \mathrm{H}, \mathrm{CH}_{3}\right) ;{ }^{13} \mathrm{C} \mathrm{NMR}\left(\mathrm{CDCl}_{3}, 125 \mathrm{MHz}\right): \delta$ 140.6, 130.1, 124.8, 122.2, 112.6, 108.9, $84.7(\mathrm{ArC} \equiv C), 75.4(\mathrm{ArC} \equiv \mathrm{C}), 43.3,31.9$, 29.63, 29.61, 29.59, 29.54, 29.49, 29.42, 29.32, 29.3, 28.9, 27.2, 22.7, 14.1; LR-MS (EI): m/z (\%): 411.3 (66), 242.1 (4), 228.1 (100), 200.1 (8), 69.1 (3); HR-MS $\left(\mathrm{C}_{30} \mathrm{H}_{37} \mathrm{~N}\right)$ : calcd 411.2926, found 411.2933; TLC $\mathrm{R}_{f}=0.42($ EtOAc/n-Hexane, 1/19, v/v).

3,6-Bis(benzoylbiphenyl)ethynyl-9-tetradecylcarbazole (3): Application of Sonogashira's general procedure for alkyne coupling ${ }^{9}$ [3,6-diethynyl-9tetradecylcarbazole (1.42 g, $3.45 \mathrm{mmol})$, 4-benzoyl-4'-bromobiphenyl (2.56 g, 7.60 mmol), $\mathrm{Pd}\left(\mathrm{PPh}_{3}\right)_{2} \mathrm{Cl}_{2}(0.29 \mathrm{~g}, 0.41 \mathrm{mmol}), \mathrm{CuI}(0.078 \mathrm{~g}, 0.41 \mathrm{mmol})$ in piperidine $(5 \mathrm{~mL})$ and THF $(20 \mathrm{~mL})]$ at $65{ }^{\circ} \mathrm{C}$ gave the product as a yellow solid $(1.78 \mathrm{~g}, 56 \%) .{ }^{1} \mathrm{H}$ NMR $\left(\mathrm{CDCl}_{3}, 500 \mathrm{MHz}\right): \delta 8.32(\mathrm{~d}, J=1.4 \mathrm{~Hz}, 2 \mathrm{H}), 7.92(\mathrm{~d}, J=8.1 \mathrm{~Hz}, 4 \mathrm{H}), 7.85(\mathrm{~m}, 4 \mathrm{H})$, $7.74(\mathrm{~d}, J=8.1 \mathrm{~Hz}, 4 \mathrm{H}), 7.66-7.71(\mathrm{~m}, 10 \mathrm{H}), 7.61(\mathrm{~d}, J=8.7 \mathrm{~Hz}, 2 \mathrm{H}), 7.52(\mathrm{~m}, 4 \mathrm{H}), 7.40$ $(\mathrm{d}, J=8.7 \mathrm{~Hz}, 2 \mathrm{H}), 4.30\left(\mathrm{t}, J=7.1 \mathrm{~Hz}, 2 \mathrm{H}, \mathrm{NCH}_{2}\right), 1.88\left(\mathrm{~m}, 2 \mathrm{H}, \mathrm{NCH}_{2} \mathrm{CH}_{2}\right), 1.20-1.40$ (m, 22H, $\left.\mathrm{CH}_{2}\right), 0.88\left(\mathrm{t}, J=6.7 \mathrm{~Hz}, 3 \mathrm{H}, \mathrm{CH}_{3}\right) ;{ }^{13} \mathrm{C} \mathrm{NMR}\left(\mathrm{CDCl}_{3}, 125 \mathrm{MHz}\right): \delta 196.3$ 
(ArCOAr), 144.4, 140.6, 139.2, 137.7, 136.4, 132.4, 132.1, 130.8, 130.0, 128.3, 127.2, $126.8,123.8,122.5,113.7,109.1,43.4,31.9,29.65,29.62,29.57,29.52,29.46,29.3$, 28.9, 27.2, 22.7, 14.1; LR-MS (FAB): m/z (\%): 924.4 (62), 740.2 (12), 670.3 (7), 460.1 (15), 307.1 (100); HR-MS $\left(\mathrm{C}_{68} \mathrm{H}_{61} \mathrm{NO}_{2}\right)$ : calcd 924.4781, found 924.4782.

Macrocycle (4): In an argon filled glove box, a solution of molybdenum triamide (7.5 $\mathrm{mg}, 0.011 \mathrm{mmol})$ and $p$-nitrophenol $(4.7 \mathrm{mg}, 0.034 \mathrm{mmol})$ in $\mathrm{CCl}_{4}(1.0 \mathrm{~mL})$ was added to a solution of 3 (104 mg, $0.11 \mathrm{mmol})$ in $\mathrm{CCl}_{4}(2.1 \mathrm{~mL})$. The flask was sealed and removed from the glove box. The resulting mixture was stirred for $22 \mathrm{~h}$ at $30^{\circ} \mathrm{C}$. After removal of the precipitate by vacuum filtration, the filtrate was concentrated in vacuo and the macrocyclic product was purified by column chromatography $\left(\mathrm{CHCl}_{3} / n\right.$-Hexane, $1 / 1$, $\mathrm{v} / \mathrm{v}$ ) followed by recrystalization from $\mathrm{CH}_{2} \mathrm{Cl}_{2}-\mathrm{MeOH}$ (1:1) to afford macrocycle 4 as a white solid (36.5 mg, 84\%). No other cyclic species or polymers were observed by FABMS and ${ }^{1} \mathrm{H}$ NMR. ${ }^{1} \mathrm{H}$ NMR $\left(\mathrm{CDCl}_{3}, 500 \mathrm{MHz}\right): \delta 8.38(\mathrm{~s}, 2 \mathrm{H}), 7.71(\mathrm{dd}, J=8.6,1.3 \mathrm{~Hz}$, $2 \mathrm{H}), 7.37(\mathrm{~d}, J=8.6 \mathrm{~Hz}, 2 \mathrm{H}), 4.28\left(\mathrm{t}, J=7.1 \mathrm{~Hz}, 2 \mathrm{H}, \mathrm{NCH}_{2}\right), 1.79\left(\mathrm{~m}, 2 \mathrm{H}, \mathrm{NCH}_{2} \mathrm{CH}_{2}\right)$, 1.20-1.41 (m, 22H, $\left.\mathrm{CH}_{2}\right), 0.88\left(\mathrm{t}, J=6.6 \mathrm{~Hz}, 3 \mathrm{H}, \mathrm{CH}_{3}\right) ;{ }^{13} \mathrm{C} \mathrm{NMR}\left(\mathrm{CDCl}_{3}, 125 \mathrm{MHz}\right): \delta$ 140.1, 129.3, 123.9, 122.6, 114.4, 108.9, 89.1 (ArC $\equiv C A r), 43.3,31.9,29.67,29.64$, 29.60, 29.55, 29.50, 29.4, 29.0, 27.3, 22.7, 14.1. MS (FAB) $\mathrm{m} / \mathrm{z}\left(\mathrm{M}^{+}\right)=1542.1$ (calcd 1542.3). GPC $1740\left(\mathrm{M}_{\mathrm{n}}\right), 1.00\left(\mathrm{M}_{\mathrm{w}} / \mathrm{M}_{\mathrm{n}}\right)$. The spectroscopic data are in agreement with those reported in the literature. ${ }^{17}$ 


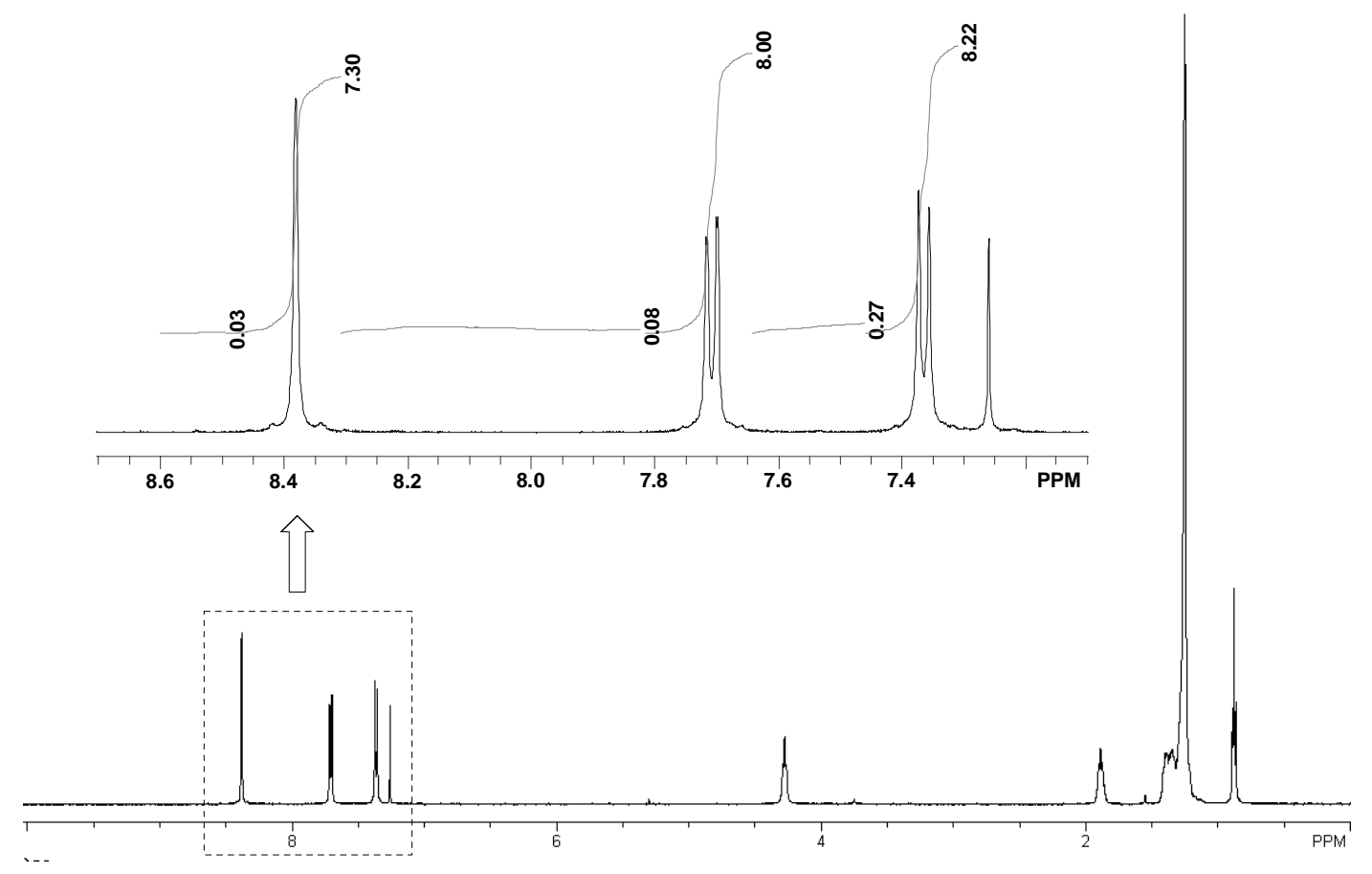

${ }^{1} \mathrm{H}$ NMR spectrum of macrocycle $4\left(\mathrm{CDCl}_{3}, 500 \mathrm{MHz}, 20{ }^{\circ} \mathrm{C}\right)$

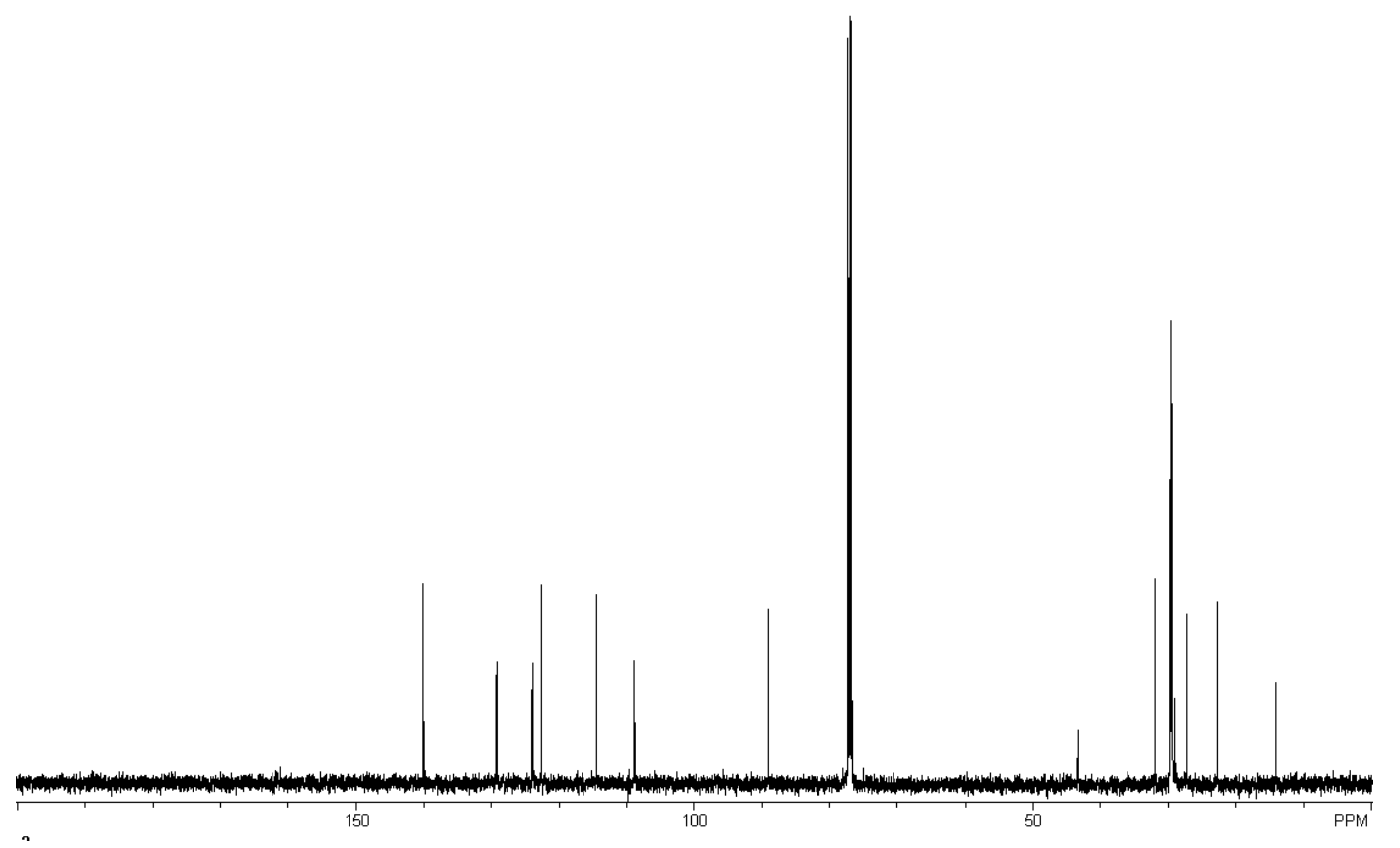

${ }^{13} \mathrm{C}$ NMR spectrum of macrocycle $4\left(\mathrm{CDCl}_{3}, 125 \mathrm{MHz}, 20{ }^{\circ} \mathrm{C}\right)$ 


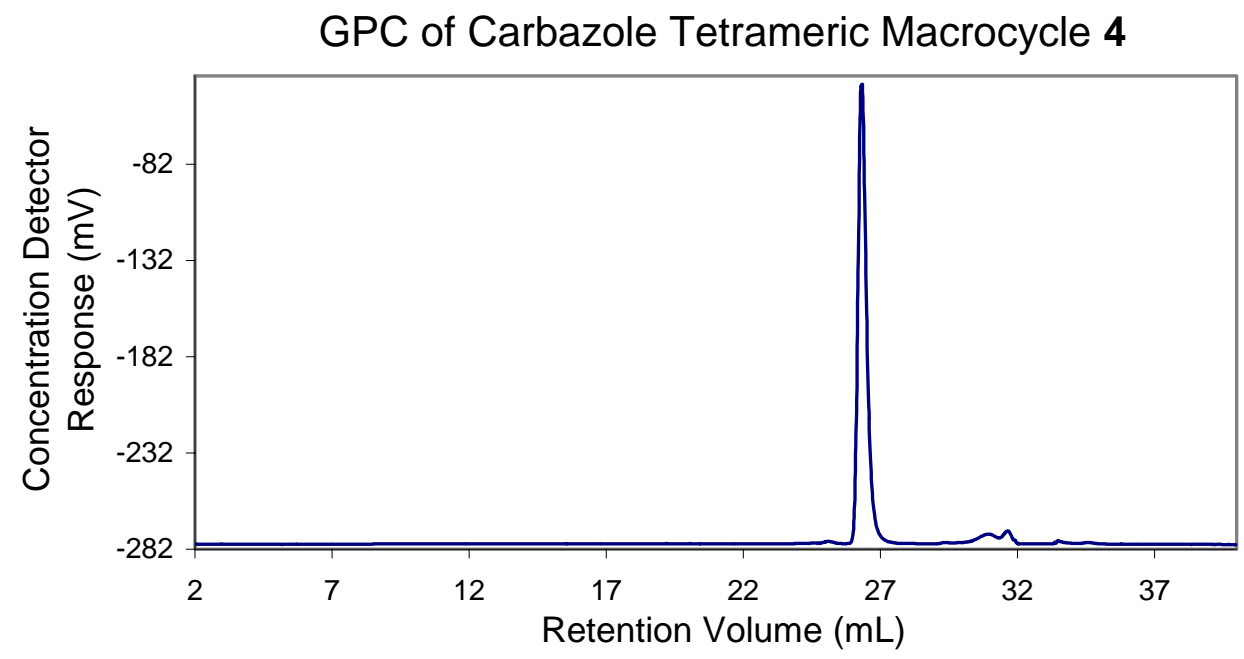

\section{References:}

1. (a) King, A. O.; Okukado, N,; Negishi, E. J. Chem. Soc. Chem. Commun. 1977, 683684. (b) King, A. O.; Negishi, E.; Villani, F. J. Jr.; Silveira, A. Jr. J. Org. Chem. 1978, 43, 358-360.

2. Ishida, T.; Iwamura, H. J. Am. Chem. Soc. 1991, 113, 4238-4241.

3. Effenberger, F.; Koch, M.; Streicher, W. Chem. Ber. 1991, 124, 163-173. Tri(ethylene glycol) monomethyl ether was used as solvent.

4. Xu, Z.; Kiang, Y.-H.; Lee, S.; Lobkovsky, E. B.; Emmott, N. J. Am. Chem. Soc. 2000, $122,8376-8391$.

5. The 3,5-dibromobenzoate ester was prepared by Fischer esterification of 3,5dibromobenzoic acid with tri(ethylene glycol) monomethyl ether.

6. Diphenylammonium triflate was prepared by mixing diphenylamine with 1 equiv triflic acid in toluene. The desired solid was isolated by filtration. 
7. Prince, R. B.; Saven, J. G.; Wolynes, P. G.; Moore, J. S. J. Am. Chem. Soc. 1999, $121,3114-3121$.

8. Crowther, G. P.; Kaiser, E. M.; Woodruff, R. A.; Hauser, C. R. Org. Synth. 1988, Coll. Vol. 6, 259-262.

9. (a) Sonogashira, K.; Tohda, Y.; Hagihara, N. Tetrahedron Lett. 1975, 4467-4470. (b) Sonogashira, K.; Yatake, T.; Tohda, Y.; Takahashi, S.; Hagihara, N. J. Chem. Soc. Chem. Commun. 1977, 291-292.

10. Zhao, D.; Moore, J. S. J. Org. Chem. 2002, 67, 3548-3554.

11. (a) Zhang, W.; Kraft, S.; Moore, J. S. Chem. Commun. 2003, 832-833. (b) Zhang, W.; Kraft, S.; Moore, J. S. J. Am. Chem. Soc. 2004, 126, 329-335.

12. The molybdenum triamide and $p$-nitrophenol were previously mixed together in 1,2,4-trichlorobenzene for $4 \mathrm{~min}$. The color of catalyst solution changed from yellow to dark red upon mixing the two species. The vacuum driven macrocyclizations can also be performed at a more dilute concentration $(0.038 \mathrm{M})$ with equal mass of monomers.

13. Ge, P.-H.; Fu, W.; Herrmann, W. A.; Herdtweck, E.; Campana, C.; Adams, R. D.; Bunz, U. H. F. Angew. Chem. Int. Ed. 2000, 39, 3607-3610.

14. Lahiri, S.; Thompson, J. L.; Moore, J. S. J. Am. Chem. Soc. 2000, 122, 11315-11319.

15. Zhang, J.; Pesak, D. J.; Ludwick, J. L.; Moore, J. S. J. Am. Chem. Soc. 1994, 116, 4227-4239.

16. Shetty, A. S.; Zhang, J.; Moore, J. S. J. Am. Chem. Soc. 1996, 118, 1019-1027.

17. Maruyama, S.; Hokari, H.; Wada, T.; Sasabe, H. Synthesis 2001, 1794-1799. 